\title{
Preaching to episodic ears: Practicing a dramaturgical homiletic
}

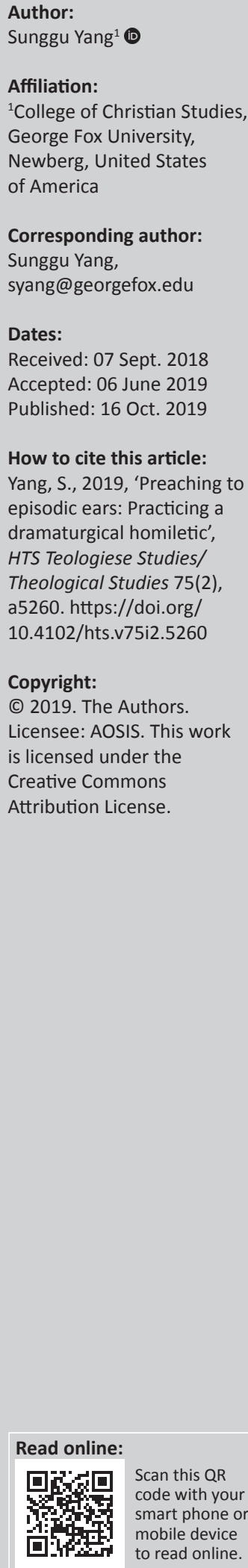

This article is a critical attempt to develop a homiletic methodology for preaching to the episodic self of the 21st century. The British philosopher Galen Strawson contends that postmodern people today do not regard themselves as living out their lives in a diachronic or narrative sense, but rather in an episodic-existential sense. This episodic-existential way of perceiving one's life has recently posed a significant challenge to the current preaching practice that is mostly composed and delivered from the pulpit through a narrative. This article provides a considerate response to that episodic-existential challenge. Specifically, the article proposes a dramaturgical narrative form of preaching, in close collaboration with Paul Tillich's existential theology, as a creative alternative to the conventional narrative way(s) of preaching.

Keywords: Homiletic; Episodic; Galen Strawson; Existential; Paul Tillich; Narrative; Dramaturgical.

\section{Introduction}

\author{
Our peace in His will \\ And even among these rocks \\ Sister, mother \\ And the Spirit of the river, spirit of the sea, \\ Suffer me not to be separated \\ And let my cry come unto Thee.
}

\section{- T. S. Eliot (1958:67)}

North American Christians sitting in the pews on Sundays do not seem to pay careful attention to sermons delivered in a narrative style. Among many reasons for that, a crucial one is that - as the British philosopher Galen Strawson (2008:189-207) argues - people nowadays do not perceive themselves as living out a narrative in their daily lives; rather they know themselves and perceive their lives in an episodic sense. ${ }^{1}$ In other words, people do not much value the stories of their own past nor do they live as though the past stories form their lives; rather they prefer to live out an episodic present moment as their own existential identity. ${ }^{2}$ Whether this episodic claim is true or not, it is evident that in American pews today, narrative-oriented preaching is losing its effectiveness in terms of audibility and inspiration in the congregation, as Thomas G. Long has observed (2009:1). On the contrary, episode-oriented (or simply, episodic) preaching is being reclaimed from the congregation's side. Does then narrative preaching have an inescapable fault within it, so that it will inevitably lose sermonic effectiveness? Or is an appropriate usage of narrative preaching not being applied in pulpits? Thomas G. Long's argument takes the latter position. For Long, proper and revised narrative preaching matters greatly today. He says, 'As for now, a chastened, revised, theologically more astute, and biblically engaged form of narrative preaching endures, and will continue to endure', even though narrative preaching will not last forever in American pulpits as the best form of preaching (Long 2009:26). As Long argues, there is no doubt that narrative preaching still has its own merits in mainline American pulpits, and will not disappear in the near future. However, it is also compelling that the current form of narrative preaching needs its own reconstruction to survive and be more inspiring to its audience.

1.Strawson (2008:189-207) further argues that living out one's life in a narrative sense is not only against one's own life experience, but also a false way of living.

2.Strawson (2004:444-445) uses two terms of story (or narrativity) and memory almost synonymously. For Strawson, memory is at best considered awareness of disparate past events that can be easily deceptive, faulty or altered. Thus, memory cannot really be a primary source by which one constructs their own identity. It is worthy of note that other philosophers and psychologists largely agree with Strawson, like Brewer (1988), Wagenaar (1994) and Scoville and Milner (1957:11-21). Strawson uses the term story as a narrated conscious stream of past memories or a collective whole of particular memories. He realises that people today tend not to establish their life's meaning with past stories like before. This argument of Strawson will be challenged (or modified) later in this article. 
What methodology and form of preaching can then be adopted and applied towards a revised narrative preaching?

Given Strawson's argument for an episodic life, the current congregational claim for a different form of preaching, and Long's search for a revised narrative preaching, my article aims to suggest a creative alternative narrative or inductive form of preaching which targets the episodic congregation. ${ }^{3}$ Of course, however, this does not mean that Strawson's episodic claim is totally acceptable or that the current and urgent congregational need for a different form of preaching is to be immediately met by any hastily crafted hodgepodge of new preaching forms. This only means that we preachers need to pay pastoral attention to the spiritual needs of the congregation today, ${ }^{4}$ and are obligated to provide the people in the pews with the Word that still nurtures and sustains the whole person, as effectively as possible.

I will find the theological ground for an alternative narrative form of preaching in Paul Tillich's existential theology. Even though his theology seems to be out of date, or a theological cliché to some people today, it still conveys very useful truths, especially to the current episodic congregation. On the ground of Tillich's existential theology, my article then examines a dramaturgical narrative form of preaching while borrowing some practical literary techniques from McMahan, Funk and Day in their book, The Elements of Writing about Literature and Film (1988). The article will finally introduce an alternative narrative form of preaching - that is, the dramaturgical narrative form built upon Tillich's existential theology - as a helpful and effective method for preaching to the episodic congregation. In this regard, I adopt theological-literary construction as my main methodology. Existential theology - and the corresponding literary-communicative form - will help construct an innovative episodic-narrative style preaching.

Because of the main focus on the construction of a new sermon form, this article's discussion on potentially new ways of biblical interpretation that fit this new sermon form will be limited.

\section{Paul Tillich's theology in relation to an episodic perspective}

Paul Tillich's theological approach is an ontological and existential one. It is ontological in the way that his theology deals with fundamental questions and answers about the human being while his methodology is pointedly existential (Tillich 2000:126). ${ }^{5}$ From his ontological and existential

3.Long (2009:18-23) provides four principles (yet not a methodology in a technical sense) for a revised narrative preaching: (1) narrative as dress rehearsal, (2) narrative as congregational canon, (3) narrative as a means for remembering the lost and silenced, and (4) narrative as a process for coming to faith. Even though this article does not discuss or utilize these principles in a methodological sense, his strong argument on narrative itself is adopted and considered throughout the article.

4.Tisdale (2010) in her groundbreaking work, Preaching as Local Theology and Folk Art, rediscovered the significance of studying or 'exegeting' the congregation for the effective sermon, the main thesis of which was again confirmed by another trendsetting effective sermon, the main thesis of which was again confirmed by another trendsetting work, Listening to Listeners by Ronald J. Allen et al. (2004). Both works affirm that listening patterns, the more receptive the congregation is to the preacher's message.

5.Tillich (2000:126) realises that there are three meanings of the term, existentialism existentialism as point of view, existentialism as protest and existentialism as perspective, the conception of God and human being equips itself with new empirical ideas, and thus any discussion about God appears to be synonymous with a discussion about the very foundation of human existence. This is why in his theology God is called 'the power of being', 'being-itself', 'the ground of being and meaning', 'God as living', and 'God as creating' (Tillich 1976:I; 235-237). This newly found God by Tillich finds God's 'being-itself' in the very existential ground of human beings, and vice versa. Of course, God is still God. God is not a perfect moral human being or merely a human being's unknown universal spirit. But God is the God who, as the human's ontological ground, nurtures and sustains human spirit. People, who once have been estranged from God, the very ground of their being, are warmly invited to be reunited with this God at the ground level of their existence seeking salvation from their ultimate despair and anxiety. By being united with God or being 'the new being in Jesus as the Christ as the power of salvation', humans can truly 'be' by obtaining 'the courage to be' (Tillich 1976:II; 165; 2000:186).

In this respect, Tillich's existential theology might seem to both start and end with 'existence-talk' or 'ontological-talk', as if his theology was closed in its little 'existential box' so that there might be no room for a broad historical or biblical link in his theology. However, Tillich's theological scope is far beyond any narrowed theological existentialism. He explicitly implicates the Bible, church history, and the history of religion and culture as key sources of his systematic theology (Tillich 1976:I; 40). The Bible is the primary source because:

$[I] \mathrm{t}$ contains the original witness of those who participated in the revealing events [of God]. The inspiration of the biblical writers is their receptive and creative response to potentially revelatory facts ... [and] their acceptance of Jesus as the Christ, and with him, of the New Being, of which they became witnesses. (Tillich 1976:I; 35)

Church history is also needed for his theology because it is the mother's womb where the Bible was formed. Lastly, the general history of religion and culture is also important for Tillich's theology. He does not forget that a theologian is an offspring of the surrounding philosophical, cultural, linguistic and religious traditions in which he or she socially and individually encounters with reality (Tillich 1976:I; 38). This reality is broader than the theologian's own theological interpretation of that reality, even though this does not mean that the theologian's perspective is wrong or does not convey any truth. It only means that at any moment, the theologian is working in and communicating with a broader context than his or her own theological world.

Through this broad understanding of the Bible, church history and the history of religion and culture, Tillich establishes his ontological or existential theology. This is why his existential expression. He specifically takes the third meaning for his own use. He says,
'Existentialism as expression is the character of the philosophy, art, and literature of
the period of the World Wars and an all-pervading anxiety of doubt and
meaninglessness. It is the expression of our own situation' (author's own italics). 
approach to the human situation and God is not ecstatic, individualistic or other-worldly. Rather, being realistic, relational (Tillich 1976:II; 59-60), ${ }^{6}$ and situational, his existential gospel has the salvific power over individuals who have been estranged both from God and one another (Long 2009:3).

In Tillich's theology, there are two great existential theological merits by the usage of which we may approach the episodic congregation more effectively. Firstly, Tillich's existential theology recognizes the people's episodic present moment as their own existential identity. Indeed, this is where the narrative-oriented preaching is losing its effectiveness on its episodic congregation. Normally, narrative preachers:

[L]ure people along on a journey of exploration and surprise with real-life stories and questions to the place where they could exclaim, 'Aha! I get it!' at the end of the sermon. (Long 2009:3, [author's own italics])

In this sermonic journey or preaching narrative towards the exclamation of 'Aha', what is tacitly assumed is that a person is now living out a narrative life and finds his or her ethical norm in the narrative outlook on one's life; thus, the sermonic form ought to take the narrative form to align the preaching moment with one's narrative thinking and narrative life itself. However, as Strawson's case reveals and Long notices, people sitting in the pews today find themselves living an episodic life rather than a narrative one, and want the preacher's sermon to touch their episodic present moment which is their compelling present identity. Thus, they may find the sermonic journey towards the 'Aha' moment too loose and adynamic to touch their immediate selves and urgent spiritual needs. This is exactly why we find Tillich's existential theology useful to reach the episodic congregation during the preaching. Tillich's existential theology converges on people's urgent claim that the focus should be on their immediate fundamental reality - the faithful claim of an intimate or present God as 'being-itself' or 'the power of being' - and the emphasis on an individual (not individualistic) self-becoming a 'new being' in Christ. Thus, in Tillich's theology, we find the God who touches an individual's present self in urgent spiritual need as well as the human being who will exclaim 'Aha' each moment whenever he or she is met by 'the power of being', but not necessarily at the end of the sermon.

Secondly, Tillich's existential approach can be a useful tool for preaching to the episodic congregation, because his existential gospel embodies a realistic, relational and situational nature in itself because of its grounding in the broad understanding of the Bible, church history and the history of religion and culture. Even though Strawson argues that episodic people do not (or do not have to) live in a diachronic or narrative sense, they all (including Strawson!)

6.Regarding the relationship among humans, he says, "Man finds himself togethe with his world in existential estrangement, unbelief, hubris, and concupiscence. Each expression of the estranged state contradicts man's essential being, his Each expression of the estranged state contradicts man's essential being, his
potency for goodness. It contradicts the created structure of himself and his world potency for goodness. It contro
and their interdependence'. must realise that they still live under an overarching (not necessarily, Christian) life narrative. In other words, they still know that their lives are the present continuation of the past and that they will participate in the continuation of the present. Strawson (2008) himself says:

I have absolutely no sense of my life as a narrative with form. Absolutely none. Nor do I have any great or special interest in my past. Nor do I have a great deal of concern for my future ... The way I am now is profoundly shaped by my past, but it is only the present shaping consequences of the past that matter, not the past as such. (pp. 194, 198)

In this somehow agitated argument, Strawson's thesis makes clear that only the 'present self' matters to him as an episodic person. Nonetheless, he still realises that he is the continuation of the past and will be the future continuation of the present. Hence, even though this continuation of himself does not inevitably lead to valuing the past or the future as a special concern, Strawson already realises that he himself would be nobody without the past and cannot deny that there is an overarching continuation of his life towards his future. Simply put, the continuation of the past, persistence of the present and inevitability of the future all exist to an episodic person, but this concept does not matter much, because the present moment is considered the most significant. Indeed, this kind of episodic notion of one's life does not necessarily contradict the narrative notion of Christian life.

Definitely, Christian life values the past as the realm of the creator's revelation and often seriously reflects on the past as the time and place of human sinfulness and its recovery. At the same time, and more importantly, Christian emphasis on the past or reflection on the past is ultimately for the people of the present. In other words, Christians look back at the past for the well-being of the present. This is the same with the relationship to the present and future. Christian individuals of the present have a great deal of concern for their own future and collectively hope for a better future. They know that this hope has a great potential to bring a better future both for individuals and society. Hence, they do hope for a better future and orient their present selves towards it.

At the same time, however, this hope for a better future deeply matters to them as far as the hope itself benefits, reorients and transforms their present selves and present society. Thus, in Christian life, we find a grand overarching narrative that binds the past and the future to the present. Here, we find ourselves to be nobody without the past and understand that our existence will participate in the inevitable future.

Returning to Tillich, we may recognise that his existential gospel contains this notion of life's grand overarching narrative. While he places strong existential emphasis on the present self, at the same time, his broad understanding of the Bible, church history and the history of religion and culture relates the present self to a bigger narrative of life than their own person. This is why Tillich's gospel can be so situational 
(or existential), relational and realistic, yet still appeal to the episodic congregation through its grand overarching frame of Christian narrative.

In the next section, I will try to develop an alternative narrative preaching methodology or preaching form based on Tillich's existential understanding of God and the human condition. However, I will not be able to do that by standing solely on the ground of Tillich's theology - because his theology alone does not provide any helpful narrative form, but only a theological and narrative foundation. Hence, I will adopt and incorporate some helpful and relevant literary techniques with Tillich's theology.

\section{A dramaturgical narrative form of preaching and Tillich's existential theology}

I propose a dramaturgical $\operatorname{plot}^{7}$ (form) for sermons as an alternative existential-narrative preaching form. This plot has five basic sermonic movements: hook (beginning), development, climax (gospel existentialised ${ }^{8}$ ), renaming and implication ${ }^{9}$ and denouement. ${ }^{10}$ Basically, this methodology takes a dramaturgical-narrative form of preaching. A question is then raised here: 'Would episodic people today listen to this other style of narrative or a diachronic sermon to its end?' Many people today still like to watch soap operas or serial dramas. More specifically, they like dramatic characters, plots, developments and scenes. Further, when their favourite dramatic books and plays are made into films, people do not hesitate to rush to their local theatres to watch the plot-thick stories. ${ }^{11}$ One crucial reason why people still like dramas is this: They find, experience and identify dramatic characters' episodes as their own and enjoy imagining their own versions of life episodes developed from drama episodes. ${ }^{12}$ Of course, dramatic films

7.Already two decades ago, Buttrick (1988:292-293) argued for the sermon 'plot' as general concept in his publication. He says, "At minimum we may describe sermons
as "plotted" scenarios for conscience. So much, by way of a glossary, for the term "plot"'. Lowry (2000:xxi) also accepts the concept of plot when he says, 'I propose "plot"'. Lowry (2000:xxi) also accepts the concept of plot when

8.I use the term, 'existentialise', throughout the article, as the verb form of existentialism, especially Tillich's theological existentialism.

9.By 'renaming' and 'implication,' I specifically mean that the preacher names what happened in the climax and draws out the implications of it.

10.I adopt and adapt basic components of the drama plot (or the theater play plot) found in Elizabeth McMahan et al.'s The Elements of Writing about Literature and Film (1988:48-49). They introduce and explain five basic components of the drama plot: (1) exposition as 'the revelation of facts, circumstance, and past events', (2) rising action as 'the building of interest through complication of the conflict'; (3) climax as 'the turning point of the play ... once reached, it becomes a point of (3) climax as 'the turning point of the play ... once reached, it becomes a point of no return'; (4) falling action as 'the unraveling of the plot during which events fall into place and the conflict moves toward final resolution' and (5) denouement as 'the explanation or outcome of the action'. As is clear, I do not adopt these plot elements for my dramaturgical form of preaching without any adaptation in term of their contents and element titles, because preaching itself is a different genre of the literature and requires unique literary flow and contents. Later, in this chapter, their adaptation for use in preaching is discussed.

11.According to a study released by The National Endowment for the Arts, in 2009 alone Americans spent more than $\$ 10$ billion, with 3.4 million people attending movies each day (Zongker 2011).

12. Halliwell (1998:VI.2, VI.9) knew well this human penchant for drama in saying, "Drama], then, is an imitation of an action that is serious, complete, and a certain magnitude; in language embellished with each kind of artistic ornament, the several kinds being found in separate parts of the play; in the form of action, not of narrative; through pity and fear effecting the proper purgation of these emotions ... narrative; through pity and fear effecting the proper purgation of these emotions ...
For [drama] is an imitation not of men, but of an action and of life, and life consists or plays often take and proceed in a diachronic structure. Moreover, a drama is not simply a carefully arranged series of certain characters' episodes but a deftly structured story with a timely sense of the past, present and future. This is why some people are easily bored by watching (long and often dull) dramas. However, it is also true that no matter how well drama is diachronically structured, people enjoy a variety of episodes of characters within it - if only because the episodes reflect their own life experiences and feelings. Besides, when the episodes have some perceived truths in them, people become more inclined to watch them over again, in order to compare their own life to those of the characters, and finally refine or develop their own episodes upon serious comparison and careful consideration.

Therefore, I contend that a dramaturgical narrative form (plot) of sermon has possible benefits in it both for preachers who want to make an effective delivery of sermon and for the episodic congregation whose present existential selves expect to be met with and touched by the 'being-itself' or 'the power of being' within the grand overarching frame of Christian narrative.

The basic logic of this dramaturgical narrative form is simple yet profound; the sermon still should be narrative in a dramaturgical sense and as a whole, yet episodic in each preaching moment. This basic but profound logic is to be applied to each movement of the dramaturgical plot of the sermon, the movement grounded upon and dictated by Tillich's existential theology so that each movement should be episodic or existential.

Our next concern is then about how the five basic movements - hook (beginning), development, climax (gospel existentialised), renaming and implication and denouement - should begin, proceed and end in a technical sense. Before we explore this issue in detail, we need to keep in mind two important things: (1) each movement must be a dynamic segment of meaningmaking dictated by the existential approach of theology in order for the whole sermonic movement to be episodic in its very nature and (2) however, there will still be an overarching or grounding dramaturgical narrative which brings each movement into unity so that no episodic movement will go off in any dissenting directions by its existential or degradedindividualistic nature.

For the existential-theological purpose of developing a sermonic plot, I divide the five dramaturgical movements into three groups: (1) hook and development (setup and setout), (2) climax (confrontation and resolution: gospel existentialised) and (3) renaming and implication, and

in action, and its end is a mode of action, not a quality'. And so did Augustine and Henry Chadwick (2008: III.ii.1, Ill.iii.3) in saying 'But what sympathy can a man have with the fictitious production of the sta? with the fictious production of the stage? As a mo called on to help the characters, but merely invited to suffer; the more he suffers, is not tha he is not that I do not pity now, but in those days, at the theatre, I rejoiced with the lovers, when they had sinful enjoyment of each other, notwithstanding the fact that their deeds were imaginary and all part of the show; and when they lost each other, I grieved with them as if in sympathy'. 
denouement (reorientation of the self). This three-grouped dramaturgical form of sermon can be described as follows.

\section{Hook and development (setup and setout) through a Tillichian approach}

McMahan et al. (1988:48) describe the first component of the drama plot as exposition, which is 'the revelation of facts, circumstance, and past events' and the second, rising action, as 'the building of interest through complication of the conflict'. Thus, exposition is the beginning of a particular narrative when the basic context of the plot is set and some characters are introduced, but it is not necessarily a place of conflict or a heavy complication of an issue.

Rising action is the place where the conflict develops and is escalated. These two components of the drama plot can be applied to our sermon plotting in two ways. Firstly, just like exposition, the sermon beginning needs to set up the basic context of the whole sermonic narrative and implicitly or explicitly introduce a sermon idea (or characters in some cases such as storytelling preaching for children). Secondly, it will be appropriate that the sermon plot will develop in a way that complicates the basic context and ideas of the sermon. However, sermon plot is not completely the same as the drama plot in terms of its beginning and development. It is different in at least two ways. Firstly, sermons frequently need a hook moment at the beginning. As sermons are generally delivered within a relatively short period of time, the speaker should, in order to best utilize this time, use a hook to draw the audience's attention. So, the beginning of the sermon is not merely a simple setting up of the basic context or an introduction of interesting ideas, but it is the moment of an effective hook of attention. ${ }^{13}$ Secondly, the sermon does not necessarily develop by the complication of conflict in the same way that a drama plot does. Rather, in many cases, it develops by exploring, revealing and communicating with the audience's inner selves and their broader context. The complication of conflict is just one aspect of the sermon development. ${ }^{14}$

Hence, a proper synthesis of the two positive applications from the drama plotting and two unique characteristics of the sermon plotting will make an effective alternative sermon beginning and its desired development (which I call the Hook and Development or Setup and Setout of the sermon). Especially when Tillich's existential theological approach dictates this alternative sermon beginning and development, the sermon

13.According to Long (2005:173-174), however, there is a caution to the emphasis on the sermon beginning as a listener hook. He says, 'Most hearers, unless they have been knocked into semiconsciousness by an unbearably tedious liturgy, come to the moment of the sermon with an air of expectancy and a genuine readiness to listen ... It would be more accurate to say that sermon introductions must not lose the listeners' attention'. Hence, at the beginning of the sermon, we need to be careful not to manipulate or forcibly grab listeners' attention, but to let listeners freely participate in the sermon.

14.This second point starkly distinguishes my existential dramaturgical methodology or plot of preaching from Lowry's (2000:1-26) so-called 'homiletic plot'. He insists (and indeed commands) that the sermon beginning creates an unmistakable narrative conflict as a hook or basic setup for the rest of the sermon. Then, the preacher should use almost the half of the sermon in complicating and intensifying preacher should use almost the half of the sermon in complicating and intensifying
the initial conflict or tension towards the eventual resolution at the end. will be able to catch the initial attention of the episodic people ${ }^{15}$ and develop in the continuing psychological and spiritual contact with them. ${ }^{16}$

\section{Climax (confrontation and resolution: gospel existentialised)}

After the sermon hooks the episodic congregation's attention and develops in the ground of the Tillichian existential approach, we need to change gears to the confrontational and resolutive stage and language in order to obtain a proclamatory moment in our sermon. At this point, we have already escalated listeners' expectation for the Word that would resolve their existential-theological tensions revealed through Tillichian ethos and thus strike their present selves. McMahan et al. (1988:47) describe this movement of the dramaturgical plot as climax, which is 'the turning point of the play ... once reached, it becomes a point of no return'. This is a powerful and valuable statement that can be aptly applied to the sermon climax. At this climax movement, we preach God's word or Christ's sheer presence here and now which would confront the episodic congregation's existential experiences and then resolve the existential tensions in the power and care of the good news proclaimed. Tillich himself (1994:100) in his sermon has a powerful moment of existential proclamation at the climax when he states, 'You are accepted ... simply accept the fact that you are accepted [by God]!' Once this existential encouragement is proclaimed, there can be no point of return. There are two ways left for the episodic audience, acceptance of being accepted or denial of being accepted. At this point, the denial of being accepted does not mean a simple return to his or her previous existential situation without God, but it rather means an ultimate estrangement away from God; thus, not a simple return but an eventual separation from God.

By the existential good news proclaimed in God's overarching love and care, the sermon message will go easily beyond the limit of a mere self-talk and self-centred pity - a well-known phenomenon of degraded existentialism. Rather, at climax we encounter the real 'ground of being', 'the power of being' and 'God as living' in our deep existence, and thus are led to infuse the profound rapture of God's acceptance into our very life circumstance.

15. There is one critical caution when we adopt and utilise Tillichian theology and philosophy in our sermons. It is well known that his theology is a negative theology in a sense. He starts his theology from revealing and interrogating human beings' existential despair or decadence, and then moving towards positive God-talk. In existential despair or decadence, and then moving towards positive God-talk. In
this respect, when we uncritically utilise Tillichian theology at the beginning of the this respect, when we uncritically utilise Tillichian theology at the beginning for the
sermon, we may have the problem that we always start our sermon from the sermon, we may have the problem that we always start our sermon from the
listeners' despairing life experiences. Hence, we need to be wise and cautious in order not to easily and always start our sermon with human decadence when we use Tillichian theology.

16. As discussed, episodic people such as Strawson highly value the present moment of their own experiences. Yet, they also have and carry their past experiences or life memories as their own, but what is profoundly significant for them is what is happening in this moment and how they are experiencing it here and now. Therefore, as listeners of the sermon they would like to hear what is now found in their experience in the present moment. Moreover, if they do not find somethin that pertains to their present experience at the beginning of the sermon, they will that pertains to their present experience at the beginning of the sermon, they will easily get bored into sleep. To draw their momentary attention into the sermon at the beginning, using Tillichian existential-theological language as the listenercatching hook will be very helpful. Tillich's theology and his philosophy know how to discover, interrogate and tell human beings' present or existential experience of the self, society and God. Especially, his languages of courage, anxiety, oneself, despair, encounter, acceptance, and so on, can be key tools that might be utilised for the preacher to engage in the episodic congregation's present self-experience. 


\section{Renaming, implication and denouement (reorientation of the self)}

At this last movement of the dramaturgical sermon plot, the sermon aims to reset up episodic selves in the broad Christian narrative. In other words, the sermon's content in this movement is designed to lead listeners' episodic selves to taste the overarching Christian meaning of life found in both their existential life narratives and the biblical narratives, particularly exploring the variety of dramaturgical characters in the Bible, including the central character, the incarnate Christ. Of course, here the episodic listeners are not to be forced to give up their episodic selves or to adopt diachronic selves (which are now strange to them). That would not happen anyway, and, of course, it is not necessary. However, the purpose of this concluding stage is to invite the episodic selves into the narrative world of the Bible, the church and the denied narrativity of their own lives, in order to help them find their own places in the Christian narrative just as they are. If this invitation is successful, some episodic people might give up their extreme episodic selves for narrative selves or some episodic listeners might just enjoy their own episodic selves appropriately placed in the Christian existential narrativity. ${ }^{17}$ Either case is perfectly acceptable and neither one can claim to be better. The most important thing in this denouement is that episodic hearers are no longer the people who lock themselves in their own present - that is, private world of the self, but become the people who open the self to the other and the broad Christian narrative in which they would find the very origin of themselves, namely God, the 'Ground of Being'.

To summarise, the dramaturgical narrative form of the sermon starts, develops and ends on the ground of the existential-theological narrativity of Christianity. This first means that from the beginning of the sermon, both the preacher and the congregation will engage in the explicit or implicit life struggle that all humans face.

Throughout the preaching moment, we come to communally confront, wrestle with and try to make theological sense of our existential realities. Do we then have a hopeful potential for success at making theological sense in our preaching? Fortunately, yes. For we, the preachers, conjure and preach the overarching existential narrativity of Christianity, wherein we can be united with God as Narrative Ground of our beings, God as Living Self, and God as Acceptance. Episodic selves in the pews today yearn for this God and this gospel, and will be drawn to the preaching which enlivens this gospel within their deep existential selves in each episodic moment.

\footnotetext{
17.This espisodic-narrative purpose and result of the sermon denouement well echoes what McMahan et al. (1988) mean when they describe the last two plot movements of the drama, as (1) falling action or 'the unraveling of the plot durin which events fall into place and the conflict moves toward final resolution' and (2) denouement as 'the explanation or outcome of the action'. During the las movements of the sermon, the listener's existential tension (or inner conflict) generated long before by the separation from 'the ground of being' moves towards final resolution; and that resolution asks for their new action as new beings in the inal resolution, and that resolution asks for their new action as new beings in the overarching Christian narrative of liberation and salvation. One primary difference, however, between my proposed sermon plot and the literary drama plot in terms of denouement is that the sermon focuses on the people themselves as new beings and active participants in the resolutive result, while it is the grand resolution itself of the literary conflict that is often fully satisfactory for the plot of any drama. A drama does not necessarily seek to confront people with newly found selves or to provoke them to deep inward searching.
}

\section{Conclusion}

I am the Alpha and the Omega, the beginning and the end.

- Revelation 21:6

$[G o d]$ gives us rest in [God's] eternal Presence.

- Tillich (1963:132)

Strawson (2008:205) explains well the current episodic congregation's mindset when he says, 'The business of living well is, for many, a completely non-Narrative project'. The episodic people in the pews today, therefore, do not perceive their lives as narratives and do not seem to be attracted much to the typical narrative preaching. They do not subscribe to the premise that people live out a narrative life and thus do not find meaning in the narrative world or the narrative imagination. Instead, they prefer to live as the episodic present moment leads them, creating in each moment their own existential identities. Discerning whether their episodic claim is justified or not in a theological or ontological sense is not our primary concern here as preachers. (For whether we like it or not, it is the way people think and behave in today's cultural context.) Rather, our first concern is how to approach and effectively provide to all people, episodic or not, the Word which we hold as the ultimate truth.

So, I have adopted Tillich's existential theology as a possibly effective theological ground for two good reasons. Firstly, his theology articulates well the human's existential present moment, which describes the episodic person's present identity. Of course, Tillich's theology did not target the episodic people of today as his original audience. Nonetheless, we still find strong merits in his theology which are helpful to approach the episodic congregation's existential identity. Secondly, even with its emphasis on the present existential moment, Tillich's theology also acknowledges the overarching Christian narrativity of human life, which is God's grand salvific drama towards human beings. This is a very important aspect of his theology that can be applied to preaching to the episodic congregation, because even though such congregations praise and live out the present moment as their own existential identities, they cannot but accept that they are also living in an overarching continuation of life. This continuation of life is reinterpreted and even transformed as it converges with God's grand salvific drama in the preaching moment.

On the ground of Tillich's theological interpretation of humanity and God, I then adopted and adapted the dramaturgical plot for creative use in the sermon. The drama plot was my particular choice, because we, including episodic people, still find ourselves enjoying drama characters, plots, developments, scenes and resolutions. By watching dramas, we reflect on our own lives and even sometimes resolve our problems. Moreover, the drama knows how important each dramatic moment is in relation to the whole dramatic narrative. Thus, I find it appropriate to adopt and adapt the drama plot as an alternative narrative preaching plot because preaching is basically all about God's salvific drama for all humans.

Finally, I find any existential and dramaturgical discussion of preaching possible only because we have God who is the 
Alpha and Omega in God's own cosmic drama and in whose eternal presence we find true and everlasting rest of our existential selves.

\section{Acknowledgement Competing interest}

The author declares that they have no financial or personal relationships that may have inappropriately influenced them in writing this article.

\section{Author contributions}

I declare that I am the sole author of this research article.

\section{Ethical considerations}

This article followed all ethical standards for carrying out research without direct contact with human or animal subjects.

\section{Funding}

This research received no specific grant from any funding agency in the public, commercial, or not-for-profit sectors.

\section{Data availability statement}

Data sharing is not applicable to this article as no new data were created or analysed in this study.

\section{Disclaimer}

The views and opinions expressed in this article are those of the authors and do not necessarily reflect the official policy or position of any affiliated agency of the authors.

\section{References}

Allen, R.J., McClure, J.S., Andrews, D.P., Bond, L.S., Moseley, D.P. \& Lee, R.G., Jr., 2004 Listening to listeners: Homiletical case studies, Chalice Press, St. Louis, MO.

Augustine and Henry Chadwick, 2008, Confessions, Oxford University Press, Oxford.

Brewer, W.F., 1988, 'Memory for randomly sampled autobiographical events', in U. Neisser \& E. Winograd (eds.), Remembering reconsidered: Ecological and traditional approaches to the study of memory, pp. 21-90, Cambridge University Press, Cambridge.

Buttrick, D., 1988, Homiletic: Moves and structures, Fortress Press, Philadelphia, PA.

Eliot, T.S., 1958, The complete poems and plays 1909-1950, Harcourt, Brace, New York.

Halliwell, S., 1998, Aristotle's poetics, University of Chicago Press, Chicago, IL.

Long, T.G., 2005, The witness of preaching, 2nd edn., Westminster John Knox Press, Louisville, KY.

Long, T.G., 2009, Preaching from memory to hope, Westminster John Knox Press, Louisville, KY.

Lowry, E.L., 2000, The homiletical plot, expanded edition: The sermon as narrative art form, Westminster John Knox Press, Louisville, KY.

McMahan, E., Funk, R. \& Day, S., 1988, The elements of writing about literature and film, Macmillan, New York.

Scoville, W.B. \& Milner, B., 1957, 'Loss of recent memory after bilateral hippocampal lesions', Journal of Neurology, Neurosurgery, and Psychiatry 20, 11-21. https:// doi.org/10.1136/jnnp.20.1.11

Strawson, G., 2004, 'Against narrativity,' Ratio, XVII 4, 428-452. https://doi.org/ 10.1111/j.1467-9329.2004.00264.x

Strawson, G., 2008, Real materialism and other essays, Oxford University Press, Oxford.

Tillich, P., 1963, The eternal now, Scribner, New York.

Tillich, P., 1976, Systematic theology I -II, University of Chicago Press, Chicago, IL.

Tillich, P., 1994, 'You are accepted', in C. Plantinga \& T.G. Long (eds.), A chorus of witnesses: Model sermons for today's preacher, p. 100, Eerdmans, Grand Rapids, Ml.

Tillich, P., 2000, The courage to be, 2nd edn., Yale University Press, New Haven, CT.

Tisdale, L.T., 2010, Preaching as local theology and folk art, Fortress Press, Minneapolis, MN.

Wagenaar, W., 1994, 'Is memory self-serving?', in U. Neisser \& R. Fivush (eds.), The remembering self: Construction and accuracy in the self-narrative, pp. 41-54, Cambridge University Press, Cambridge.

Zongker, B., 2011, 'NEA study finds Americans spend more on art than on movies', The Huffington Post, 30th April 2011, viewed 01 March 2018, http://www. huffingtonpost.com/2011/04/30/national-endowment-for-th_n_855787. html. 